\title{
SCIENTIFIC AND EXPERIMENTAL SUBSTANTIATION OF DEVELOPMENT AND APPLICATION OF DISINFECTANT OF COMBINED ACTION
}

\author{
Iakubchak O. M., Midyk S. V.
}

\section{INTRODUCTION}

Chemical disinfectants and their effects on microorganisms are sufficiently studied. Many foreign and domestic scientists have been engaged in research ${ }^{1,2,3,4}$.

Most chemicals used for disinfection do not have a pronounced specificity and have a detrimental effect not only on harmful microorganisms but also on beneficial ones, which are usually more sensitive and die in the first place. This leads to the appearance in the biocenosis of biological cavities, which are immediately filled with more active parasitic species. Long-term use of the same chemical causes the appearance of resistant forms of microorganisms ${ }^{5,6}$.

The researchers proved that in weak solutions of disinfectants, resistant microorganisms are rapidly selected, and contamination of working solutions of disinfectants reaches $20 \%$. Further, these resistant populations of microorganisms will also be resistant to higher concentrations of disinfectants, which will lead to wasted costs for disinfection measures and to the possible complication of the epidemic situation. It is also known that the sensitivity of microorganisms to disinfection in different countries, and even in different regions of one country, varies and depends on the peculiarities of the local microflora, period and methods of application of individual disinfection drugs. This can be prevented by mandatory testing of each new disinfectant introduced in the region on local microbial strains ${ }^{7,8}$.

\footnotetext{
${ }^{1}$ Поляков А.А. Ветеринарная дезинфекция. Москва : Колос, 1975.560 с.

2 Ветеринарна дезінфекція, дезодорація, дезінсекція, дезінвазія, дератизація: Інструкція. Київ, 2005. Затверджено науково-методичною радою Державного департаменту ветеринарної медицини Міністерства аграрної політики України 23 грудня 2005 р. (протокол № 3). URL: https://www.asf.vet.ua/index.php/ purpose-project/about-asf/dezinfektsiia/236-vetery-narna

${ }^{3}$ Полякова О.Р., Кузьмин В.А., Данко Ю.Ю., Фогель Л.С., Кисиль А.С. Ещенко И.Д. Дезинфекция в системе противоэпизоотических мероприятий : учебно-методическое пособие. Санкт-Петербург : ГАВМ, 2016. 14 c. URL: https://e.lanbook.com/book/121295

${ }^{4}$ Moore G., Schelenz S., Borman A. M., Johnson E.M., Brown C.S. Yeasticidal activity of chemical disinfectants and antiseptics against Candida auris. Journal of Hospital Infection. 2017. Vol. 97 (4). P. 371-375. https://doi.org/10.1016/j.jhin.2017.08.019

${ }^{5}$ Кухтин М.Д., Болтик Н.П., Рущинська Т.М., Крижанівський Я.Й., Салата В.З., Коваленко В.Л. Ефективність сучасних дезінфікувальних і мийнодезінфікувальних засобів для санітарної обробки молочного обладнання. Вісник аграрної науки. 2020. № 5 (806). С. 77-82.

${ }^{6}$ Гаркавенко Т.О., Козицька Т.Г., Горбатюк О.І., Коваленко В.Л. Вивчення стійкості антибіотикорезистентних штамів S. aureus до дезінфікуючих засобів з різними діючими речовинами. Scientific and Technical Bulletin of State Scientific Research Control Institute of Veterinary Medical Products and Fodder Additives and Institute of Animal Biology. 2019. T. 20 (2). C. 183-193. https://doi.org/ 10.36359/scivp.2019-20-2.24

${ }^{7}$ Palii A.P., Nanka O.V., Kovalchuk Y.O., Kovalchuk A.O., Kalabska V.S., Kholod I.V., Pobirchenko O.M., Umrihina O.S., Poliakov A.M., Ishchenko K.V., Paliy A.P. Effect on the bactericidal device for
} 
When choosing a disinfectant or method of disinfection, it is necessary to take into account that its disinfecting effect depends on a number of factors, namely:

1) the degree of the endurance of microorganisms (their physical condition, the presence of capsules, vegetative form or spores);

2) the specificity of the selected substance, for example, the sensitivity of typhoid bacteria to chlorine-containing substances is much lower than dysentery bacteria;

3) the concentration of the solution - its bactericidal value increases with increasing concentration, but to a certain level;

4) the temperature of the solution, because in the vast majority of substances bactericidal activity increases with increasing temperature;

5) $\mathrm{pH}$ of the medium - the activity of alkalis decreases in an acidic environment, and vice versa. In addition, $\mathrm{pH}$ significantly affects the activity of chlorine and its compounds (iodophors). For example, clarified chlorinated lime with a content of $10 \%$ active chlorine at $\mathrm{pH} 4.0$ and a temperature of $20{ }^{\circ} \mathrm{C}$ inactivates anthrax spores in 5-10 minutes, and at $\mathrm{pH} 11.0$ - in 180 minutes;

6) physical and chemical nature of the disinfection object (concrete, wood, metal, plastic).

As a result of disinfection, $99.99 \%$ of microorganisms are killed, but the viability of $0.01 \%$ of the most resistant of them is preserved ${ }^{9,10}$.

Currently, a number of domestic and imported disinfectants are used in veterinary practice in Ukraine, but most of them do not fully meet modern requirements of versatility, stability in transportation, solubility in water, activity against a wide range of microorganisms, safety for humans and animals, indifference to various construction materials. Structures and materials, environmental safety, the moderate unit cost of working solution, etc. Therefore, there is an urgent need to develop multicomponent disinfectants of combined action, which, in addition to bactericidal and antiviral action, would have insecticidal and disinvasive properties ${ }^{11,12,13}$.

decontamination the air microorganisms in poultry house on the content of toxic gases. Ukrainian Journal of Ecology. 2020. Vol. 10 (1). P. 24-29. http://doi.org10.15421/2020 4

${ }^{8}$ Kovalenko V.L., Kovalenko P.L., Ponomarenko G.V., Kukhtyn M.D., Midyk S.V., Horiuk Yu.V., Garkavenko V.M. Changes in lipid composition of Escherichia coli and Staphylococcus areus cells under the influence of disinfectants Barez ${ }^{\circledR}$, Biochlor ${ }^{\circledR}$ and Geocide ${ }^{\circledR}$. Ukrainian Journal of Ecology. 2018. 8(1): 547-550. https://doi.org/10.15421/2018 248

${ }^{9}$ Палій А.П., Гужвинська С.О., Іщенко К.В. Методичні аспекти щодо визначення бактерицидних властивостей дезінфектантів. Вісник Державного аграрно-економічного університету. 2018. № 1-2. C. $80-84$.

${ }^{10}$ Voitsitskiy V.M., Danchuk V.V., Ushkalov V.O., Midyk S.V., Kepple O.Yu., Danchuk O.V., Shevchenko L.V. Migration of antibiotics residual quantities in aquatic ecosystems. Ukrainian Journal of Ecology. 2019. Vol. 9(3), 280-286. https://doi.org/10.15421/2019_742

${ }_{11}$ Мідик С.В., Полтавченко Т.В. Якість дезінфекції на потужностях, які підлягають ветеринарносанітарному контролю та нагляду. Ветеринарна біотехнологія. Бюлетень. 2013. Випуск 23. С. 393-396.

${ }^{12}$ Цвіліховський В.І., Мідик С.В., Сисолятін С.В. Аналіз сучасного ринку дезінфекційних засобів в Україні. Наукові здобутки молоді у виріменні актуальних проблем виробництва та переробки сировини, стандартизації $і$ безпеки продовольства : Збірник праць за підсумками II Міжнародної 
A promising area for the creation of new and improvement of existing disinfectants is the development of complex drugs with synergistic action, which include several active substances from different classes of chemical compounds. The purpose of creating such drugs is to expand the range of antimicrobial activity and the ability to prevent the emergence of resistant microorganisms. In addition, these disinfectants must also have antiviral and fungicidal action and be environmentally friendly ${ }^{14}$.

Not only bactericidal action on a wide range of microorganisms is essential for the development of modern disinfectants, but also the ability to destroy both pathogens of parasitic diseases in the environment and insects, which can be factors in the transmission of dangerous pathogens common to animals and humans.

The development of a new Desainsect disinfectant has made it possible to improve the quality of preventive and compulsory disinfection at state veterinary inspection facilities, combine disinfection with disinsection and disinvasion of premises and minimize the negative impact of the drug on animals and humans and the environment.

\section{Materials and methods}

The research was conducted at the Department of Veterinary Sanitary Examination and in the training, research and production clinic of the Institute of Veterinary Medicine and Quality and Safety of Livestock Products NAU, in the slaughterhouse of the consumer society "Payovyk" (Brovary district of Kyiv region); at the dairy complex LLC "Rainbow" (Brovary) and CJSC "Krasnogirske" Zolotoniyskiy district of Cherkasy region; on the basis of open joint-stock company "Brovary-milk" (Brovary); in the Central State Laboratory of Veterinary Medicine, as well as on the basis of LLC SPE "UKRVAK" (Brovary) and the sanitary-epidemiological station of Sviatoshynskyi district of Kyiv.

Areas of research: creating a recipe for a new drug; study of bactericidal, disinvasive and insecticidal properties of the drug; improvement of methods for determining the effectiveness of decontamination of surfaces from viruses; study of toxic and corrosive effects of the drug.

The development of the formulation of the drug Desainsect was carried out based on the physicochemical properties of its components. At the same time

науково-практичної конференції молодих вчених, аспірантів і студентів, 20-22 квітня 2012 р. Київ : ТОВ «Аграр Медіа Груп». С. 548-549.

13 Коваленко В.Л., Гаркавенко В.М., Пономаренко Г.В., Пономаренко О.В., Кухтин М.Д., Коваленко П.Л. Ефективність і безпечність препарату «Барез» за аерозольної обробки приміщень у присутності тварин. Науково-технічний бюлетень НДЦ біобезпеки та екологічного контролю ресурсів АПК. 2018. Т. 6. № 1. С. 46-51.

${ }^{14}$ Палій А.П., Завгородній A.I., Бондарчук А.О. Бактерицидні властивості засобу «DOROSEPT SUPER» щодо мікобактерій. Вісник Полтавської державної аграрної академії. 2019. № 4. C. 159-165. https://doi.org/10.31210/visnyk2019.04.20 
achieved good solubility of all components in the water at different temperatures, the absence of sediment and flakes on the surface of the solution, turbidity, odor. The absence of chemical interaction between the active substances of the drug during their mixing was established and the indifference of the components was ensured.

The bactericidal effect was studied according to the method described in the Recommendations for the sanitary-microbiological examination of washes from the surfaces of test objects ${ }^{15}$. To determine the bactericidal action of the disinfectant strains of E. coli ATCC 25922 (seeding on KODA medium), S. aureus ATS 25923 (seeding on salt meat-peptone broth) were used at a concentration of 2 billion $/ \mathrm{cm}^{3}$ and $0.05 \%, 0.1 \%, 0.2 \%, 0.5 \%, 1 \%$ solutions of the Desainsect. The working volume of disinfectant per test object was $4-5 \mathrm{~cm}^{3}$ with exposure of 10, 40 and $60 \mathrm{~min}$. and 10 days. Authentic test objects treated with the same amount of sterile water were selected for control. To determine the tuberculocidal effect was used strain Mycobacterium bovis IEKVM-1.

Virus-acidity was determined by suspension and decontamination of test object surfaces using the La Sota vaccine strain of Newcastle disease virus. $0.1 \%, 0.2 \%, 0.5 \%$ and $1.0 \%$ the Desainsect concentrations were used.

To study the disinvasive action of the Desainsect, 200 infested faecal samples were selected and formed three experimental and one control group from each animal species (10 faecal samples in each group). Samples of the I experimental group were treated with $2.5 \%$ solution of the Desainsect, II $-3 \%$, III $-3.5 \%$ solution of the Desainsect at the rate of $200 \mathrm{~cm}^{3} / \mathrm{m}^{2}$.

To obtain larvae, faecal samples were placed in Petri dishes for 4-6 days at a temperature of $26^{\circ} \mathrm{C}$. The presence of eggs in the faeces was determined by the Fulleborn method. Eggs and larvae in faecal samples from cattle and pigs were identified by an animal helminth atlas (2001).

Residual insecticidal action was studied in 3 experimental and 1 control group of Musca domestica, 10 individuals each. Used $0.02 \%$ (I experimental), $0.03 \%$ (II experimental) and $0.04 \%$ (III experimental) solutions of the Desainsect for the active insecticide, the consumption of the active substance was $0.08 \mathrm{~g} / \mathrm{m}^{2}$.

To determine the acute toxicity of the Desainsect, 7 experimental and one control group of white mice (10 animals each) were formed. Mice in the control group were administered orally $1 \mathrm{~cm} 3$ of water. And the experimental group was orally administered the drug at a rate of $400 \mathrm{mg} / \mathrm{kg}$ body weight; II - 600; III - 800; IV - 1000; V - 1200; VI - 1300 and VII experimental group $-1400 \mathrm{mg} / \mathrm{kg}$ body weight of the disinfectant solution. The results of lethal doses of the drug were calculated by the method of Kerber and Prozorovsky.

\footnotetext{
15 Рекомендації щодо санітарно-мікробіологічного дослідження змивів із поверхонь тест-об'єктів та об'єктів ветеринарного нагляду і контролю. Затверджено Міністерством АПК 23.12.2004 р. Київ : Видавничий центр НАУ, 2004. 15 с.
} 
To study the cumulative effect of the Desainsect, experimental and control groups of white mice, 10 heads in each were formed; for the study of skin resorptive action - two experimental and one control group of white mice. For 15 days for two hours a day, the tails of experimental mice were immersed in tubes with $0.5 \%$ and $5.0 \%$ solutions of the Desainsect. The tails of control animals were placed in test tubes with water.

Irritant and sensitizing effects were studied in guinea pigs. Five experimental and one control group of guinea pigs, 10 animals each, were formed. Used $2 \%$ (I experimental), 4\% (II experimental), 6\% (III experimental), 8\% (IV experimental), $10 \%$ (V experimental group) drug concentration.

Animal studies have been performed in compliance with the requirements of the European Convention for the Protection of Pets.

White mice were used to detect pathological and anatomical changes in the tissues and organs of animals after administration of lethal and working concentrations of the drug. Of these, 15 individuals were I, II and III experimental groups; 16 individuals - control. Mice of the experimental group I were orally administered $1 \mathrm{~cm}^{3}$ of $0.2 \%$ working solution of the Desainsect; II - $861 \mathrm{mg} / \mathrm{kg}$ (LD50) of the Desainsect; III - $1400 \mathrm{mg} / \mathrm{kg}$ $\left(\mathrm{LD}_{100}\right)$ of the Desainsect. Animals in the control group were injected with $1 \mathrm{~cm}^{3}$ of water.

The spleen, liver, several parts of the small and large intestines, heart, kidneys, lungs were taken for histological examination during the autopsy of laboratory animals and fixed in a neutral buffered solution of formalin according to Lilly (1969).

The corrosive effect of the Desainsect was determined by the method of RG Alagezyan (1981). The studies used $0.5 ; 1.0 ; 1.5 ; 2.5 \%$ solutions of the Desainsect. For comparison, $2 \%$ sodium hydroxide solution $(\mathrm{NaOH})$ was used, the results were calculated according to the method of determining and evaluating the corrosion activity of detergents and disinfectants.

In order to determine the residual amounts of the drug on the surfaces of the test objects were disinfected with $0.2,0.5$ and $1 \%$ solution of the Desainsect with exposure, respectively, 60,30 and 10 minutes, at a flow rate of $200 \mathrm{~cm}^{3} / \mathrm{m}^{2}$. Then, the test objects were washed with distilled water (flow rate $1000 \mathrm{~cm}^{3} / \mathrm{m}^{2}$ ). The water used to wash the test items was collected in appropriate containers and examined. Control test items, after similar disinfection, were also washed with distilled water, which was tested for chlorine content. The premises of the training clinic after disinfection were washed with tap water (water consumption $-1000 \mathrm{~cm}^{3} / \mathrm{m}^{2}$ ). Water, which was washed away after the consumption of $1000 \mathrm{~cm}^{3} / \mathrm{m}^{2}$, was collected in a container and used to determine chlorine residues. Samples of the first flushing water were examined from the control surfaces of the room after disinfection. Residues of the drug after disinfection were determined by the iodometric method. 
Statistical processing of experimental data was performed in Microsoft Office Excel. The degree of probability was assessed by Student's test.

\section{Research results and their analysis}

Over the last 10 years, more than 60 detergents and disinfectants have been registered for use in veterinary medicine in Ukraine, the vast majority of which are imported. Among them, however, there are no drugs of combined action. Therefore, there is a need to develop and implement new disinfectants that are characterized by bactericidal and insecticidal action and would be effective for disinfection of premises.

The formulation of the Desainsect drug was developed, based on the physicochemical properties of its components. The purpose of creating the drug was to achieve a wide range of action, as well as to combine in one drug disinfection, disinvasive and insecticidal properties.

The following chemical substances were included into the disinfection agent: 1,3-dichlorantine, 5,5-dimethylhydantoin, sodium tripolyphosphate; sulfonol; corrosion inhibitor, acetamiprid (insecticide), sodium chloride and flavouring. In choosing the components of the Desainsect, we focused on 1,3-dichlorantin and 5,5-dimethylhydantoin because, unlike other chlorinecontaining substances, they do not form harmful trihalomethanes and have strong bactericidal properties. It should be noted that acetamiprid, due to the chemical structure of molecules and different sensitivity of insect and mammalian receptors, has a selective toxic effect, and has a high biological activity against a wide range of insect pests and its low toxicity to mammals. It is also low-toxic to bees and bumble, has low rates of expenditure $\left(0.05 \mathrm{~g} / 100 \mathrm{~cm}^{3}\right.$ solution), moderately resistant to environmental objects.

Having determined the bactericidal dilution and the phenolic coefficient, we found that the bactericidal action of the Desainsect is 131.5 times stronger than the bactericidal action of carbolic acid. The average protein index is 2.76 .

\section{Disinfecting effect of the Desainsect drug}

Studies have shown that at $0.05 \%$ concentration, the Desainsect inhibits the growth of E. coli ATCC 25922 on smooth surfaces of test objects (stainless steel, tile). On rough surfaces (concrete, brick) E. coli continues to grow. $S$. aureus after treatment with the same concentration continued to grow on all surfaces. Starting at $0.1 \%$ concentration, when disinfecting test objects, the Desainsect completely destroys $E$. coli and $S$. aureus within 10, 40, 60 minutes and 10 days.

It should be noted that in Ukraine there is a limited range of disinfectants that have a tuberculocidal effect. In this regard, we tested the effectiveness of the Desainsect on the pathogen of tuberculosis (strain M. Bovis IEKVM-1). The mechanism of action of chloro-active drugs on Mycobacterium 
tuberculosis is explained by the oxidation process, according to which oxygen and chlorine oxidize the microbial cell. The bactericidal action of chlorinated drugs depends on the concentration of chlorine or atomic oxygen. After conducting a number of studies, we found that the Desainsect in $1 ; 2.5$ and $3 \%$ concentrations at 1 and 3 hours exposure, has a bactericidal effect on the pathogen of tuberculosis (M. bovis IEKVM-1) in the laboratory. This was confirmed by staging a bioassay on guinea pigs. All animals remained alive for three months. During the pathological and anatomical autopsy of guinea pigs killed after the experiment, no accumulations of exudate and transudate were found in the body cavities, the pleura and peritoneum were not changed. No changes characteristic of tuberculosis, such as tubercles in organs, orchitis, diffuse caseous inflammation, lymph node hyperplasia, etc. were detected.

As a result of industrial research it was found that in the washes taken after disinfection by $0.1 \%, 0.2 \%, 0.5 \%, 1.0 \%$ solutions of the Desainsect, $E$. coli and $S$. aureus were not detected.

It should be noted that Newcastle disease in poultry remains particularly dangerous and causes significant economic damage to livestock in Ukraine. Examining the virodal activity of the drug during disinfection of surfaces with the existing method, it was found out that it has a number of drawbacks: samples with content contaminated with concomitant microflora. In addition, in the process of neutralizing the disinfectant, the virus-containing material is diluted, which significantly reduces the sensitivity of the method. In order to eliminate these shortcomings, the method of determining the effectiveness of decontamination of surfaces contaminated with viruses has been improved, which includes determining the virocidal action of disinfectants and monitoring the effectiveness of decontamination of surfaces of test objects. According to this method, $5 \%$ bentonite gel $\left(0.1 \mathrm{~cm}^{3}\right.$ per 1 sample $)$ was added to the virus-containing liquid at $\mathrm{pH} 4.5-5.0$, followed by desorption of viruses into an alkaline solution ( $\mathrm{pH} 9.0)$ of $0.05 \mathrm{M}$ tris-buffer solution $\left(1-2 \mathrm{~cm}^{3}\right.$ per 1 sample) and determined the presence of viruses in chicken embryos.

We found that at a concentration of $0.1 \%$, the drug inactivates the virus with an efficiency of $45.77 \pm 0.77 \%$ in 15 minutes; in 30 minutes - by $91 \pm 1.21 \%$, and in 1 hour $-99 \pm 0.70 \%$. Under the action of $0.2 \%$ solution, in 15 minutes, $99.80 \pm 0.2 \%$ of virions were neutralized. Complete inactivation of the virus $(100 \%)$ is achieved by treatment with $0.2 \%$ solution of the Desainsect - in 30 minutes. Under the action of $0.5 \%$ and $1 \%$ disinfectant solution, there is a complete inactivation of the virus in 15 minutes. The results of studies performed by the suspension method are shown in table 1 .

As can be seen in table 1 , in $0.5 \%$ and $1.0 \%$ of the Desainsect concentrations have severe virocidal activity and can already be in 15 minutes. Completely inactivated the virus of Newcastle poultry disease. 
Inactivation of Newcastle disease virus

by means of the Desainsect, $M \pm m, n=6$

\begin{tabular}{|c|c|c|c|c|}
\hline \multirow{2}{*}{$\begin{array}{l}\text { Exposition } \\
\text { (min.) }\end{array}$} & \multicolumn{4}{|c|}{ The Desainsect concentration, $\%$} \\
\hline & 0.1 & 0.2 & 0.5 & 1 \\
\hline 15 & $\frac{10^{9.25 \pm 0.17}}{43.77 \pm 0.56^{*}}$ & $99 . \frac{10^{6.5 \pm 0.55}}{90 \pm 0.10^{* *}}$ & $\underline{0}$ & $\frac{0}{100}$ \\
\hline 30 & $90 . \frac{10^{8.5 \pm 0.39}}{90 \pm 0.62} * *$ & $\frac{0}{100}$ & $\underline{\underline{0}}$ & $\underline{0} \underline{0}$ \\
\hline 60 & $99 . \frac{10^{7.5 \pm 0.51}}{00 \pm 0.60} * *$ & $\underline{0} \underline{0}$ & $\underline{\underline{0}}$ & $\underline{0}$ \\
\hline
\end{tabular}

Note: Probability of difference: $* \mathrm{P} \leq 0.05 ; * * \mathrm{P} \leq 0.01$. The initial titer of Newcastle disease virus $-10^{9.5} \mathrm{IDM}_{50} / \mathrm{cm}^{3}$. The numerator indicates the residual infectivity of the virus in $\lg \mathrm{IDM}_{50} / \mathrm{cm}^{3}$. In the denominator - the efficiency of virus inactivation, $\%$.

\section{Disinvasive action of the Desainsect}

During the study of faecal samples from control and experimental groups of animals infested with helminth larvae, the following results were found: in each of the faecal samples from cattle, the intensity of invasion ranged from 40 to 75 larvae of the Strongyloides type; in samples from goats - 6-8 larvae of nematodes; 30-40 roundworm larvae and 50-60 Oesophagostomum larvae were detected in each pig faecal sample; in each sample from ducks 10-12 capillaries and 15-18 ascarids from chickens.

Invaded samples were treated with $2.5 \%, 3 \%$ and $3.5 \%$ the Desainsect solutions at the rate of $1.4 \mathrm{~cm}^{3}$ of the Desainsect per Petri dish $\left(200 \mathrm{~cm}^{3} / \mathrm{m}^{2}\right)$ and left in the thermostat for 1 and 2 hours. To the faeces of the control group of animals was added $1.4 \mathrm{~cm}^{3}$ of tap water at room temperature.

The Desainsect, at a concentration of $2.5 \%$, destroys $92 \%$ of the larvae of Strongyloides spp. in 1 hour and in 2 hours - 98.5\%; Nematodirus spathiger larvae through 1 hour - by $97.2 \%$, after 2 hours - 98.7\%; nematode Ascaris suum after 1 hour - 89\%, after 2 hours - 96.5\%; Oesophagostomum dentatum 93.5\% and, respectively $-98.2 \%$; Thominx contorta, respectively $-99 \%$ and $100 \%$; Ascaridia galli $-96.8 \%$ and $99.5 \%$, respectively.

Therefore, starting from 3\% concentration, the Desainsect completely inactivates the larvae of all studied species of pathogens after 1 hour.

\section{Insecticide action of the Desainsect}

In order to give the drug an insecticidal effect, acetamiprid was introduced into its composition. The study was performed by treatment with different concentrations of the drug, the surfaces of the plates on which were planted houseflies. According to the results of research it was found that when treated with $0.02 \%$ solution (acetamiprid), the highest residual insecticidal effect of 
the drug was $90 \%$ and it was observed on the $3^{\text {rd }}-6^{\text {th }}$ day; on the $14^{\text {th }}$ day $40 \%$, and on the $21^{\text {st }}$ day - only $10 \%$. When treating surfaces with $0.03 \%$ solution, $90-100 \%$ of flies died on the $2^{\text {nd }}-7^{\text {th }}$ day. For $0.04 \%$ of the drug concentration on the $1^{\text {st }}$ day, $90 \%$ of houseflies died, during the $2-7^{\text {th }}$ day $100 \%$; on day 14 and $21,60 \%$ and $30 \%$ of houseflies died, respectively.

According to the results of the conducted researches it is established that in our recommended concentration of $0.03-0.04 \%$ (for acetamiprid) $100 \%$ destruction of houseflies is achieved. The maximum insecticidal action lasts from the $2^{\text {nd }}$ to the $7^{\text {th }}$ day after treatment.

During the treatment of livestock premises, the concentrations of the Desainsect proposed by us had a prolonged insecticidal action, the manifestation of which was the best during the first 7 days after treatment from 94.87 to $87.18 \%$ (table 2 ).

Table 2

Influence of the Desainsect on the larvae of worms in the species of faecal matter farm animals and poultry, $M \pm m, n=10$

\begin{tabular}{|c|c|c|c|c|c|c|c|c|c|c|c|c|}
\hline \multirow{3}{*}{ 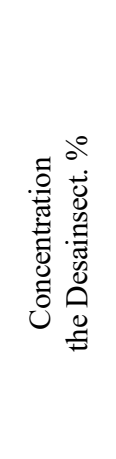 } & \multicolumn{2}{|c|}{ Cattle and goats } & \multicolumn{2}{|c|}{ Goat } & \multicolumn{4}{|c|}{ Pig } & \multirow{2}{*}{\multicolumn{2}{|c|}{$\begin{array}{c}\text { Duck } \\
\text { Thominx } \\
\text { contorta }\end{array}$}} & \multirow{2}{*}{\multicolumn{2}{|c|}{$\begin{array}{c}\text { Chickens } \\
\text { Ascaridia galli }\end{array}$}} \\
\hline & \multicolumn{2}{|c|}{ Strongyloides spp. } & \multicolumn{2}{|c|}{$\begin{array}{l}\text { Nematodirus } \\
\text { spathiger }\end{array}$} & \multicolumn{2}{|c|}{ Ascaris suum } & \multicolumn{2}{|c|}{$\begin{array}{c}\text { Oesophagostomum } \\
\text { dentatum }\end{array}$} & & & & \\
\hline & 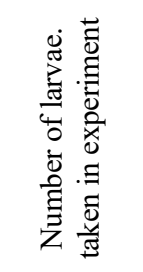 & $\begin{array}{l}\overrightarrow{\widetilde{J}} \\
\frac{\mathbb{E}}{0} \\
\partial^{\circ}\end{array}$ & 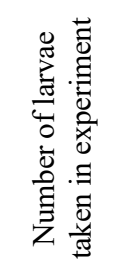 & $\begin{array}{l}\text { चृँ } \\
\frac{\pi}{0} \\
0^{\circ}\end{array}$ & 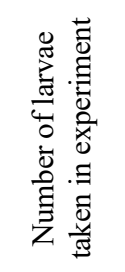 & 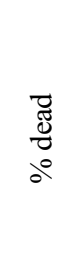 & 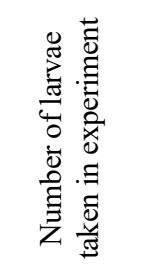 & $\begin{array}{l}\overrightarrow{\widetilde{J}} \\
\frac{\delta}{0} \\
0^{\circ}\end{array}$ & 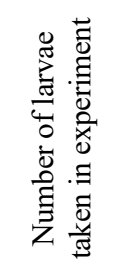 & $\begin{array}{l}\vec{\Xi} \\
\frac{\pi}{0} \\
0^{\circ}\end{array}$ & 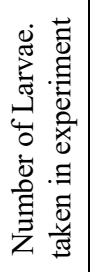 & $\begin{array}{l}\vec{\Xi} \\
\frac{\pi}{0} \\
0^{\circ}\end{array}$ \\
\hline \multicolumn{13}{|c|}{ The 60 minutes exposition } \\
\hline 2.5 & $\begin{array}{c}39.7 \pm \\
0.96 * * *\end{array}$ & $\begin{array}{l}92.0 \pm \\
1.9\end{array}$ & $5.8 \pm 0.64$ & $\begin{array}{l}97.2 \pm \\
1.1^{* *}\end{array}$ & $29.5 \pm 1.8$ & $\begin{array}{l}89.0 \pm \\
2.4\end{array}$ & $49.5 \pm 1.3$ & $\begin{array}{c}93.5 \pm \\
1.4^{*}\end{array}$ & $\begin{array}{c}10.1 \pm \\
0.92\end{array}$ & $\begin{array}{l}99.0 \pm \\
2.2^{*}\end{array}$ & $\begin{array}{c}15.3 \pm \\
0.7\end{array}$ & $\begin{array}{l}96.8 \pm \\
1.7^{*}\end{array}$ \\
\hline 3.0 & $\begin{array}{l}52.9 \pm \\
1.72 * *\end{array}$ & 100 & $6.4 \pm 0.8$ & 100 & $\begin{array}{l}30.8 \pm \\
0.84^{*}\end{array}$ & 100 & $\begin{array}{l}59.9 \pm \\
1.32 *\end{array}$ & 100 & $\begin{array}{c}10.9 \pm \\
1.32\end{array}$ & 100 & $\begin{array}{c}15.2 \pm \\
1.0\end{array}$ & 100 \\
\hline 3.5 & $\begin{array}{l}74.6 \pm \\
1.76^{*}\end{array}$ & 100 & $8.2 \pm 1.4$ & 100 & $\begin{array}{c}38.3 \pm \\
1.3^{*}\end{array}$ & 100 & $\begin{array}{c}50.3 \pm \\
1.36\end{array}$ & 100 & $\begin{array}{c}11.9 \pm \\
1.32\end{array}$ & 100 & $\begin{array}{c}17.8 \pm \\
1.04\end{array}$ & 100 \\
\hline $\begin{array}{l}\text { Control: } \\
\text { tap } \\
\text { water }\end{array}$ & $65.1 \pm 1.52$ & 0 & $6.3 \pm 0.9$ & 0 & $\begin{array}{c}28.8 \pm \\
1.24\end{array}$ & 0 & $\begin{array}{c}49.5 \pm \\
1.16\end{array}$ & 0 & $10.5 \pm 1.1$ & 0 & $\begin{array}{c}16.2 \pm \\
0.88\end{array}$ & 0 \\
\hline \multicolumn{13}{|c|}{ The 120 minutes exposition } \\
\hline 2.5 & $\begin{array}{c}39.7 \pm \\
0.96^{* * *}\end{array}$ & $\begin{array}{l}98.5 \pm \\
1.1^{*}\end{array}$ & $5.8 \pm 0.64$ & $\begin{array}{l}98.7 \pm \\
1.0^{* *}\end{array}$ & $29.5 \pm 1.8$ & $\begin{array}{c}96.5 \pm \\
1.7\end{array}$ & $49.5 \pm 1.3$ & $\begin{array}{c}98.2 \pm \\
1.3^{*}\end{array}$ & $\begin{array}{c}10.1 \pm \\
0.92\end{array}$ & 100 & $\begin{array}{c}15.3 \pm \\
0.7\end{array}$ & $\begin{array}{l}99.5 \pm \\
0.5^{* * * *}\end{array}$ \\
\hline 3.0 & $\begin{array}{l}52.9 \pm \\
1.72 * *\end{array}$ & 100 & $6.4 \pm 0.8$ & 100 & $\begin{array}{l}30.8 \pm \\
0.84^{*}\end{array}$ & 100 & $\begin{array}{l}59.9 \pm \\
1.32 *\end{array}$ & 100 & $\begin{array}{c}10.9 \pm \\
1.32\end{array}$ & 100 & $\begin{array}{c}15.2 \pm \\
1.0\end{array}$ & 100 \\
\hline 3.5 & $\begin{array}{l}74.6 \pm \\
1.76^{*}\end{array}$ & 100 & $8.2 \pm 1.4$ & 100 & $\begin{array}{c}38.3 \pm \\
1.3^{*}\end{array}$ & 100 & $\begin{array}{c}50.3 \pm \\
1.36\end{array}$ & 100 & $\begin{array}{c}11.9 \pm \\
1.32\end{array}$ & 100 & $\begin{array}{c}17.8 \pm \\
1.04\end{array}$ & 100 \\
\hline $\begin{array}{l}\text { Control: } \\
\text { tap } \\
\text { water }\end{array}$ & $65.1 \pm 1.52$ & 0 & $6.3 \pm 0.9$ & 0 & $\begin{array}{c}28.8 \pm \\
1.24\end{array}$ & 0 & $\begin{array}{c}49.5 \pm \\
1.16\end{array}$ & 0 & $10.5 \pm 1.1$ & 0 & $\begin{array}{c}16.2 \pm \\
0.88\end{array}$ & 0 \\
\hline
\end{tabular}

Notation: ${ }^{*} \mathrm{p} \leq 0.05 ; * * \mathrm{p} \leq 0.01 ; * * * * \mathrm{P} \leq 0,001$ regarding control 


\section{Toxicological characteristics of the Desainsect}

Toxicological studies are mandatory in the development of any animal protection product. We calculated the $\mathrm{LD}_{50}$ of the Desainsect by the Prozorovsky method, the results are shown in Table 3.

According to Prozorovsky's calculations, the $\mathrm{LD}_{50}$ of the Desainsect was $862 \mathrm{mg} / \mathrm{kg}$ of body weight of laboratory animals. To confirm the reliability of the obtained results, the $\mathrm{LD}_{50}$ calculation was also performed by the Kerber method. The average statistical $\mathrm{LD}_{50}$ in the seven study groups by the method of Kerber is $861.43 \pm 2.1 \mathrm{mg} / \mathrm{kg}$ body weight.

Table 3

Defining toxicity $\mathrm{LD}_{50}$ by Prozorovsky's method

\begin{tabular}{|c|c|c|c|c|c|c|c|c|}
\hline $\begin{array}{c}\text { Dose, } \\
\mathrm{mg} / \mathrm{kg} \text { body } \\
\text { weight, } \\
\mathrm{X}_{\mathrm{e}}\end{array}$ & $\begin{array}{c}\text { Morta- } \\
\text { lity, \% } \\
\mathrm{y}_{\mathrm{e}}\end{array}$ & $\begin{array}{c}\text { Place } \\
\text { Doses } \\
\mathrm{X}\end{array}$ & $\begin{array}{c}\text { Probits } \\
, \mathrm{y}\end{array}$ & $\begin{array}{c}\text { Weightin } \\
\text { g factor, } \\
\mathrm{B}\end{array}$ & $\mathrm{XB}$ & $\mathrm{X}^{2} \mathrm{~B}$ & $\mathrm{YB}$ & $\mathrm{XУB}$ \\
\hline 400 & 0 & 1.0 & 3.04 & 1.0 & 1 & 1 & 3.04 & 3.04 \\
\hline 600 & 10 & 2.0 & 3.82 & 2.9 & 5.8 & 11.6 & 11.078 & 22.16 \\
\hline 800 & 20 & 3.0 & 4.26 & 4.1 & 12.3 & 36.9 & 17.466 & 52.4 \\
\hline 1000 & 30 & 4.0 & 4.59 & 4.6 & 18.4 & 73.6 & 21.114 & 84.46 \\
\hline 1200 & 50 & 5.0 & 5.13 & 4.9 & 24.5 & 122.5 & 25.137 & 125.69 \\
\hline 1300 & 70 & 6.0 & 5.71 & 4.1 & 24.6 & 147.6 & 23.411 & 140.47 \\
\hline 1400 & 100 & 7.0 & 6.96 & 1.2 & 8.4 & 58.8 & 11.95 & 58.46 \\
\hline Amount & & & & 22.8 & 95 & 452 & 113.2 & 486.68 \\
\hline
\end{tabular}

These results allow us to conclude that the Desainsect belongs to the $3^{\text {rd }}$ class of danger (moderately toxic substances) according to the classification of toxic substances according to the degree of toxicity.

The cumulative effect was studied by observing experimental and control animals. Behavioural abnormalities, changes in the physiological functions of experimental animals and fatalities were not detected. As a result of pathological and anatomical examinations, macroscopic changes in the internal organs were not detected. This gives grounds to conclude that the Desainsect has no pronounced cumulative effect.

The sensitizing effect of the drug was studied in guinea pigs. As a result of the experiment, it was found that only in the first minutes after application of the disinfectant, the experimental animals tried to lick the drug from the treated area of skin, then they calmed down and their behaviour did not differ from normal. There was a slight reddening of the skin for 3 hours, there was no swelling. After rinsing the disinfectant with water, no signs of pathology were detected.

During the studies to determine the skin-resorptive effect of the Desainsect and after their completion, the clinical condition of laboratory mice under the action of $0.5 \%$ and $5 \%$ solutions of the Desainsect did not change. 
Histological examinations performed after the autopsy revealed acute catarrhal-hemorrhagic gastroenteritis, hemorrhagic mesenteric lymphadenitis, acute venous hyperemia of the liver, spleen, kidneys, granular dystrophy of hepatocytes and epithelial epithelium in animals of the II and III experimental groups. No pathological changes were found in the animals of the control and experimental groups According to the results of research, it can be concluded that the Desainsect in doses of $\mathrm{LD}_{50}$ and $\mathrm{LD}_{100}$ causes changes that are characteristic of most poisons of the 3 rd class of danger.

It should be noted that at a working concentration of $0.2 \%$, the drug, administered orally at a dose of $1 \mathrm{~cm}^{3}$, did not cause visible changes, confirming the results of a pathological and anatomical examination of the carcasses of slaughtered mice. This indicates low toxicity and safety of the drug for the body of laboratory animals in working concentrations.

\section{Corrosion activity of the Desainsect}

After applying the Desainsect to aluminium and stainless steel plates, their surfaces remain smooth and even. There is only slight turbidity of the aluminium and the formation of a thin gray precipitate, which after drying can be easily shaken from the plates of both types of metal.

It was found that the corrosion activity of the Desainsect in percentage terms for aluminium under the action of $0.5 \%$ solution of the drug is $0.0080 \%$; under the action of $1 \%$ solution $-0.0066 \%$; under the action of $1.5 \%$ solution $-0.0053 \%$; under the action of $2.5 \%$ solution of the Desainsect $-0.007 \%$, which, respectively, in 956375, 1159242, 1443584, 1093000 times lower, compared with the corrosion activity of $2 \% \mathrm{NaOH}$ solution (table. 4).

The degree of corrosion activity of the Desainsect

Table 4

\begin{tabular}{|c|c|c|c|c|c|c|c|}
\hline \multirow[b]{3}{*}{$\begin{array}{l}\text { Name } \\
\text { of the } \\
\text { disin- } \\
\text { fectant }\end{array}$} & \multirow[b]{3}{*}{$\begin{array}{c}\text { Con- } \\
\text { centra- } \\
\text { tion } \\
\%\end{array}$} & \multicolumn{6}{|c|}{ Type of metal } \\
\hline & & \multicolumn{3}{|c|}{ Aluminium } & \multicolumn{3}{|c|}{ Aluminium } \\
\hline & & 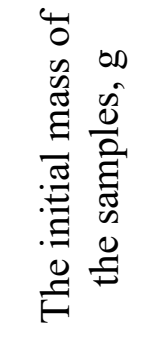 & 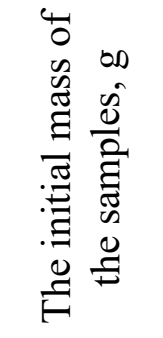 & 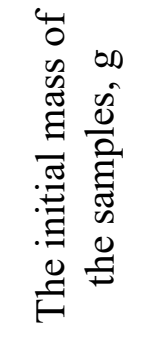 & 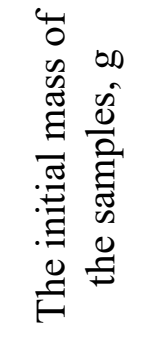 & 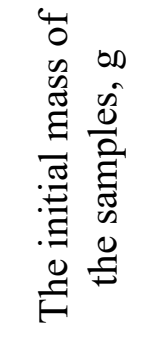 & 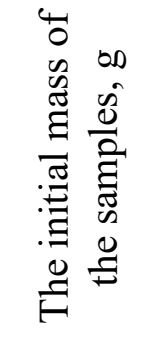 \\
\hline \multirow{4}{*}{$\begin{array}{l}\text { The } \\
\text { Desa- } \\
\text { insect }\end{array}$} & 0.5 & 2.74200 & 2.74178 & 0.00022 & 2.34445 & 2.34440 & 0.00005 \\
\hline & 1.0 & 2.11835 & 2.11821 & 0.00014 & 2.81120 & 2.81118 & 0.00002 \\
\hline & 1.5 & 3.01995 & 3.01979 & 0.00016 & 2.26330 & 2.26325 & 0.00005 \\
\hline & 2.5 & 4.73775 & 4.73742 & 0.00033 & 2.33645 & 2.33639 & 0.00006 \\
\hline $\mathrm{NaOH}$ & 2.0 & 4.90695 & 1.15265 & 3.7543 & 2.94095 & 2.94081 & 0.00014 \\
\hline
\end{tabular}


Weight loss as a percentage for stainless steel under the action of $0.5 \%$ solution of the Desainsect was $0.0021 \%$, under the action of $1 \%$ solution $0.001 \%$, with $1.5 \%$ solution $-0.002 \%$, with $2.5 \%$ solution of the Desainsect $0.0026 \%$, which, respectively, in $238.1 ; 500 ; 250 ; 192.3$ times lower compared to $2 \% \mathrm{NaOH}$ solution (table 4 ).

Therefore, all studied concentrations of the drug showed a slight, compared with the control $(2 \% \mathrm{NaOH}$ solution) corrosive effect on both aluminum samples and stainless steel samples.

\section{Determination of residual amounts of the Desainsect on the treated surfaces of test-objects and production facilities}

The content of active chlorine in water should not exceed $0.3-0.5 \mathrm{mg} / \mathrm{dm}^{3}$. When treated with $0.2 \%$ solution of the Desainsect and exposure for 10 minutes $4.95 \pm 0.45 \mathrm{mg} / \mathrm{dm}^{3}$ of chlorine remained in the water used to wash the test objects; when processing test objects with $0.5 \%$ the Desainsect (exposure 30 minutes) $-7.07 \pm 0.26 \mathrm{mg} / \mathrm{dm}^{3}$; when treated with a $1 \%$ solution (exposure 1 hour) in samples of such water remained $13.4 \pm 0.58 \mathrm{mg} / \mathrm{dm}^{3}$ of chlorine. It should be noted that after washing the test objects, pre-treated with $0.2 \%, 0.5 \%$, and $1 \%$ solutions of the drug, distilled water, no chlorine residues were detected on the surfaces.

Studies on the chlorine content were performed in water washes from the walls of the training clinic of NAU, where the animals were kept. After treatment with disinfectant and removal of disinfectant, it was found that after treatment of the walls with $0.2 \%$ and $0.5 \%$ solution of the Desainsect at exposures of $10 \mathrm{~min}$ and $30 \mathrm{~min}$, respectively, no active chlorine residues were present. After treatment with a $1 \%$ solution of the Desainsect in the first water washes revealed the content of active chlorine $0.64 \pm 0.06 \mathrm{mg} / \mathrm{dm}^{3}$. It should be noted that after washing the walls, pre-treated with $0.2 \%, 0.5 \%$ and $1 \%$ solutions of the Desainsect with tap water, no active chlorine residues were detected.

\section{Testing of the Desainsect in production conditions}

To confirm the effectiveness of the Desainsect in production conditions, disinfection was carried out in the slaughterhouse of the consumer company "Payovyk", which is located in the village. Rozhny, Brovary district, Kyiv region. The following concentrations of the Desainsect were used for disinfection: $0.1 \%, 0.2 \%, 0.5 \%, 1.0 \%$. The consumption of the drug was $200-300 \mathrm{~cm}^{3}$ per $1 \mathrm{~m}^{2}$ of area. Before disinfection, the surfaces of walls, floors and equipment were cleaned of dirt and various residues and washed with tap water. Small equipment - basins, trays, buckets, small parts of machines were washed with warm water and immersed for 30 minutes. in a bath with $1.0 \%$ solution of the Desainsect. Transporters, conveyors, which are 
in contact with food, were first washed with water, and then disinfected with brushes with $0.5 \%$ the Desainsect solution. The exposure was 30 minutes.

After disinfection, sterile swabs were taken from the floor, walls, tables, containers, utensils, conveyors, and conveyors. Tampons were immersed in tubes with sterile water and $0.1 \%$ sodium thiosulfate. The effectiveness of disinfection was determined by the absence of growth of E. coli and $S$. aureus on nutrient media after incubation of crops in a thermostat at $37{ }^{\circ} \mathrm{C}$ for 24-48 hours and after 7 days.

Therefore, after disinfection with $0.1 \%, 0.2 \%, 0.5 \%, 1.0 \%$ the Desainsect solutions in all cases there was no growth of E. coli and S. aureus.

Disinfection was also carried out by a the Desainsect at the BrovaryMoloko dairy. A $0.1 \%$ solution of the drug was used for disinfection of the equipment for 15-20 min. In the shops of the dairy dairy utensils (buckets, cans, milk meters), milk tanks, cooling tanks after using soap with warm water brushes. Disinfection was performed with $0.2 \%$ the Desainsect solution with exposure for 30 minutes Filters, towels, washed from the remnants of milk with warm water, washed in $0.5 \%$ the Desainsect solution, rinsed in warm water. Disinfection of the premises of the dairy shops was carried out by irrigating the floor and walls in concentrations: $0.1 \%, 0.2 \%, 0.5 \%, 1.0 \%$ at a flow rate of $200-300 \mathrm{~cm}^{3} / \mathrm{m}^{2}$.

Before and after disinfection, sterile swabs were taken from tanks, tanks, baths and other utensils for storing milk, milk pipes, working surfaces of filters, milk coolers and pasteurizers, floors and walls of the room. Tampons were immersed in tubes with sterile water and $0.1 \%$ sodium thiosulfate solution. In the laboratory, crops were made from each test tube.

After disinfection with $0.1 \%, 0.2 \%, 0.5 \%, 1.0 \%$ disinfectant solutions in all cases there was no growth of E. coli and $S$. aureus.

Production tests of the Desainsect were carried out on the farm of the dairy complex "Raduga", Kyiv region.

Before disinfection, manure was removed from the cowshed, milk utensils and milking equipment were rinsed with warm water. Disinfection of milk was performed with $0.5 \%$ solution of the Desainsect at an exposure of 30 minutes. Filters, towels, strainers were rinsed in warm water to remove milk residue, soaked in $0.2 \%$ the Desainsect solution and washed in warm water. Disinfection of the cowshed was performed by irrigating the walls and floor with $0.1 \%, 0.2 \%, 0.5 \%$ and $1 \%$ the Desainsect solution, using $300 \mathrm{~cm}^{3} / \mathrm{m}^{2}$, at an exposure of 30 minutes.

After disinfection, sterile swabs were taken from tanks, tanks, baths and containers for storing milk, milk pipes, working surfaces of filters, milk coolers and pasteurizers, milking machines (inner surface of teat head, inner surface of collector and fittings, milk tubes, milk tubes milking buckets), as well as from the floor and walls of the room. Tampons were immersed in 
tubes with sterile water and $0.1 \%$ sodium thiosulfate solution. All test tubes in the central state laboratory of veterinary medicine were tested for the presence of test cultures of microorganisms. After 24 and 48 hours, growth of cultures of $E$. coli and $S$. aureus was not detected.

The economic efficiency of the Desainsect was calculated based on the results of research obtained on the basis of Raduga LLC. As calculations have shown, the disinfectant developed by us is an effective and cost-effective drug when used for prophylactic disinfection.

\section{CONCLUSIONS}

A theoretical generalization is made and a new solution of the scientific problem on the development and substantiation of the formulation of a new disinfectant Desainsect is proposed. For the first time, the optimal concentrations of the drug and the effective exposure for disinfection, disinsection and disinvasion of the premises subject to veterinary and sanitary supervision were experimentally determined, and the effectiveness of its use was proved.

1. It was found that the bactericidal action of the Desainsect is 131.5 times stronger than the bactericidal action of carbolic acid. In the presence of protein, the bactericidal action of the Desainsect is reduced by 2.76 times. On the surfaces of test objects in $0.1 \%$ concentration, the Desainsect completely inactivates E. coli ATCC 25922 and S. aureus ATC 25923 for 10 minutes; at $1 \%$ concentration at an exposure of 1 hour the drug inactivates the tuberculosis pathogen Mycobacterium bovis IEKVM-1; at $0.2 \%$ concentration and at an exposure of 30 minutes, $0.5 \%$ concentration and at an exposure of 15 minutes completely neutralizes Newcastle disease virus (La Sota vaccine strain).

2. The disinvasive effect of the drug was studied: starting from 3\% concentration, the Desainsect completely inactivates the larvae of nematodes of farm animals and poultry after 1 hour.

3. The insecticidal action of the drug is proved. The best residual insecticidal action of the Desainsect on Musca domestica is achieved on the $2^{\text {nd }}-7^{\text {th }}$ day after treatment with $0.03-0.04 \%$ solution (according to the active insecticidal substance).

4. It was found that the Desainsect in terms of toxicity belongs to the $3^{\text {rd }}$ class of danger (moderately toxic substances). $\mathrm{LD}_{50}$ when administered into the stomach of animals is $861.43 \mathrm{mg} / \mathrm{kg}$. It has no pronounced signs of accumulation, causes only a slight irritant effect on the mucous membranes of the eyes; in the working concentration $(0.2 \%)$ does not cause pathological and anatomical changes in the body of experimental mice; in lethal doses causes hepatotoxic and nephrotoxic effects; the death of animals occurs from pulmonary insufficiency due to redness and swelling of the lungs.

5. The corrosion effect of the Desainsect on aluminum was studied, which when applied $0.5 \%$ solution is $0.0080 \%, 1 \%$ solution $-0.0066 \%, 1.5 \%-$ 
$0.0053 \%, 2.5 \%-0.007 \%$, that in $956375,1159242,1443584,1093000$ times lower, compared with $2 \% \mathrm{NaOH}$ solution. The weight loss of stainless steel samples as a percentage when applying $0.5 \%$ solution of the Desainsect is $0.0021 \%, 1 \%$ solution $-0.001 \%, 1.5 \%$ solution $-0.002 \%, 2.5 \%$ solution $0.0026 \%$, which, respectively, in $238.1 ; 500 ; 250 ; 192.3$ times lower compared to $2 \% \mathrm{NaOH}$ solution.

6 . The advantages of the improved method of determining the effectiveness of decontamination of the surfaces of test objects from viruses are proved. This allows you to free the samples from the accompanying microflora, which significantly increases the sensitivity of the method by preventing the dilution of virus-containing material, which occurs in the process of neutralization of the disinfectant.

7. It was established that rinsing with tap water at a pressure of $0.44 \mathrm{MPa}$ and a flow rate of $11 / \mathrm{m}^{2}$ provides complete removal of the Desainsect after treatment of livestock premises.

8. The efficiency of the Desainsect in $0.1-3 \%$ concentration at exposure of 30-60 min for disinfection, disinsection and disinvasion of premises subject to veterinary and sanitary supervision at the rate of $200-300 \mathrm{~cm}^{3} / \mathrm{m}^{2}$ has been proved.

\section{SUMMARY}

The section of the monograph focuses on the development, study and introduction of effective chemical means of preventive measures of infectious and invasive animal illnesses in Ukraine.

A recipe of new disinfection preparation is worked out. An aproximate bactericidal breeding, phenol coefficient, albuminous index and disinfection action of preparation are determined. Its effective bactericidal concentrations are set on E. coli and S. aureus on the objects of test and in the production conditions; its tuberculocide effect was proved on Mycobacterium of bovis; its viruscide effect on the virus of the Newcastle bird's desease of vaccine culture La Sota is studied. The method of distinguishing of the efficiency of surfaces disinfecting is improved, which allowed to prevent from the dilution of virus containing material. The preparation is effective for disinvasion of stock-raising apartments in case of nematodosis. An effective concentration for an insecticide action on Musca domestica has been set and its prolongation has been proved. Certain lethal toxic doses of preparation have been determined; its cumulative, irritating, skin resorptive sencitilazing effects have been checked. The macroscoric histological changes of organs of laboratory animals after the administration of working and lethal doses of preparation have been shown. The corrosive effect of preparation on metals has been studied. The presence of tailings of preparation on surfaces after disinfection is tested. 


\section{REFERENCES}

1. Поляков А.А. Ветеринарная дезинфекция. Москва : Колос. 1975. $560 \mathrm{c}$.

2. Ветеринарна дезінфекція, дезодорація, дезінсекція, дезінвазія, дератизація: Інструкція. Київ, 2005. Затверджено науково-методичною радою Державного департаменту ветеринарної медицини Міністерства аграрної політики України 23 грудня 2005 р. (протокол № 3). URL: https://www.asf.vet.ua/index.php/purpose-project/about-asf/dezinfektsiia/236vetery-narna

3. Полякова О.Р., Кузьмин В.А., Данко Ю.Ю., Фогель Л.С., Кисиль А.С. Ещенко И.Д. Дезинфекция в системе противоэпизоотических мероприятий : учебно-методическое пособие. Санкт-Петербург : СПбГАВМ, 2016. 14 c. URL: https://e.lanbook.com/book/121295

4. Moore G., Schelenz S., Borman A. M., Johnson E.M., Brown C.S. Yeasticidal activity of chemical disinfectants and antiseptics against Candida auris. Journal of Hospital Infection. 2017. Vol. 97 (4). P. 371-375. https://doi.org/10.1016/j.jhin.2017.08.019

5. Кухтин М.Д., Болтик Н.П., Рущинська Т.М., Крижанівський Я.Й., Салата В.3., Коваленко В.Л. Ефективність сучасних дезінфікувальних і мийнодезінфікувальних засобів для санітарної обробки молочного обладнання. Вісник аграрної науки. 2020. № 5 (806). С. 77-82.

6. Гаркавенко Т.О., Козицька Т.Г., Горбатюк О. І., Коваленко В.Л. Вивчення стійкості антибіотикорезистентних штамів $\mathrm{S}$. aureus до дезінфікуючих засобів з різними діючими речовинами. Scientific and Technical Bulletin of State Scientific Research Control Institute of Veterinary Medical Products and Fodder Additives and Institute of Animal Biology. 2019. T. 20 (2). C. 183-193. https://doi.org/10.36359/scivp.2019-20-2.24

7. Palii A.P., Nanka O.V., Kovalchuk Y.O., Kovalchuk A.O., Kalabska V.S., Kholod I.V., Pobirchenko O.M., Umrihina O.S., Poliakov A.M., Ishchenko K.V., Paliy A.P. Effect on the bactericidal device for decontamination the air microorganisms in poultry house on the content of toxic gases. Ukrainian Journal of Ecology. 2020. Vol. 10 (1). P. 24-29. http://doi.org10.15421/2020_4

8. Kovalenko V.L., Kovalenko P.L., Ponomarenko G.V., Kukhtyn M.D., Midyk S.V., Horiuk Yu.V., Garkavenko V.M. Changes in lipid composition of Escherichia coli and Staphylococcus areus cells under the influence of disinfectants Barez ${ }^{\circledR}$, Biochlor ${ }^{\circledR}$ and Geocide ${ }^{\circledR}$. Ukrainian Journal of Ecology. 2018, 8(1): 547-550. https://doi.org/10.15421/2018_248

9. Палій А.П., Гужвинська С.О., Іщенко К.В. Методичні аспекти щодо визначення бактерицидних властивостей дезінфектантів. Вісник Державного аграрно-економічного університету. 2018. № 1-2. С. 80-84. 
10. Voitsitskiy V.M., Danchuk V.V., Ushkalov V.O., Midyk S.V., Kepple O.Yu., Danchuk O.V., Shevchenko L.V. Migration of antibiotics residual quantities in aquatic ecosystems. Ukrainian Journal of Ecology. 2019. Vol. 9 (3), 280-286. https://doi.org/10.15421/2019_742

11. Мідик С.В., Полтавченко Т.В. Якість дезінфекції на потужностях, які підлягають ветеринарно-санітарному контролю та нагляду. Ветеринарна біотехнологія. Бюлетень. 2013. Випуск 23. С. 393-396.

12. Цвіліховський В.І., Мідик С.В., Сисолятін С.В. Аналіз сучасного ринку дезінфекційних засобів в Україні. Наукові здобутки молоді у виріменні актуальних проблем виробництва та переробки сировини, стандартизації $і$ безпеки продовольства : Збірник праць за підсумками II Міжнародної науково-практичної конференції молодих вчених, аспірантів і студентів, 20-22 квітня 2012 р. Київ : ТОВ «Аграр Медіа Груп». С. 548-549.

13. Коваленко В.Л., Гаркавенко В.М., Пономаренко Г.В., Пономаренко О.В., Кухтин М.Д., Коваленко П.Л. Ефективність і безпечність препарату «Барез» за аерозольної обробки приміщень у присутності тварин. Науково-технічний бюлетень НДЦ біобезпеки та екологічного контролю ресурсів АПК. 2018. Т. 6. № 1. С. 46-51.

14. Палій А.П., Завгородній А.І., Бондарчук А.О. Бактерицидні властивості засобу «DOROSEPT SUPER» щодо мікобактерій. Вісник Полтавської державної педагогічної академї. 2019. № 4. С. 159-165. https://doi.org/10.31210/visnyk2019.04.20

15. Рекомендації щодо санітарно-мікробіологічного дослідження змивів з поверхонь тест-об'єктів та об'єктів ветеринарного нагляду і контролю. Затверджено Міністерством АПК 23.12.2004 p. Київ : Видавничий центр НАУ, 2004. 15 с.

\section{Information about authors:} Iakubchak O. M., Doctor of Veterinary Sciences,

Professor at the Department of Veterinary Hygiene named after A. K. Skorokhodko National University of Life and Environmental Sciences of Ukraine 15, Heroyiv Oborony str., Kyiv, 03041, Ukraine

Midyk S. V., $\mathrm{PhD}$,

Head of the Research Department for Monitoring the Safety of Agricultural Products of the Ukrainian Laboratory of Quality and Safety of Agricultural Products National University of Life and Environmental Sciences of Ukraine 15, Heroyiv Oborony str., Kyiv, 03041, Ukraine 